\title{
ARTICLE
}

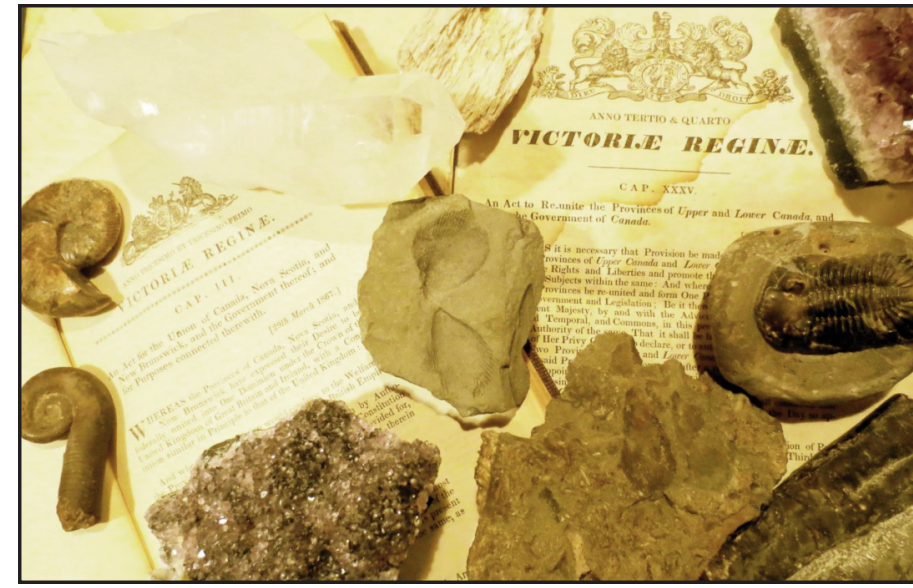

\section{Elkanah Billings: The Lawyer Who Revealed the Ancient Life of the Past}

\section{Jeffrey M. Minicucci}

\author{
Barrister-at-Law, Solicitor, and Notary Public \\ 229 Glen Park Avenue \\ Toronto, Ontario, M6B 2E2, Canada \\ E-mail:priority1mail@rogers.com
}

\section{SUMMARY}

Elkanah Billings is an important, historical example of a $19^{\text {th }}$ century Ontario lawyer who made a contribution to Canadian life by engaging in a pursuit outside the practice of law. An accomplished autodidact (i.e. a self-taught expert) and renowned as the father of Canadian paleontology, Billings has the distinction of being claimed by the global paleontological and geological professional communities, and by the Ontario legal profession. Although some researchers have alleged that Billings had abused alcohol during his life, he nonetheless managed to establish a remarkable career as a paleontologist. He applied the researching, analytical, and argumentative skills that he had acquired during his years of training and practice as a lawyer to the science of paleontology enabling him to peel back the layers of time to reveal the ancient life of the past. In view of his strengths, weaknesses, and professional accomplishments, the example of Billings' history potentially becomes increasingly relevant in the effort to reinforce the importance of ethics and professional responsibility among earth science and evolutionary biology professionals and to promote a shared sense of professional community and heritage. The example of Billings' history also presents a golden opportunity for the synthesist to nurture a closer connection between the law and science in the form of interdisciplinary or multidisciplinary dialogue and collaboration.

\section{RÉSUMÉ}

Elkanah Billings est un important exemple historique d'un avocat Ontarienne du XIXe siècle qui a apporté une contribution à la vie Canadienne en se livrant à une poursuite en dehors de la pratique du droit. Autodidacte accompli et reconnu comme le père de la paléontologie canadienne, Billings a la particularité d'être revendiqué par les communautés professionnelles paléontologiques et géologiques mondiales, et par la profession juridique de l'Ontario. Bien que certains chercheurs ont affirmé que Billings avait abusé de l'alcool au cours de sa vie, il a réussi néanmoins à établir une carrière remarquable en tant que paléontologue. Il a appliqué la recherche, d'analyse, et les compétences argumentatives qu'il avait acquises au cours de ses années de formation et de pratique comme avocat à la science de la paléontologie qui lui permet de décoller les couches de temps pour révéler l'ancienne vie du passé. Compte tenu de ses points forts, les faiblesses et les réalisations professionnelles, l'exemple de l'histoire Billings devient potentiellement plus pertinent dans les efforts visant à renforcer l'importance de l'éthique et de la responsabilité professionnelle des sciences de la terre et les professionnels de la biologie de l'évolution et de promouvoir un sens partagé de la communauté professionnelle et le patrimoine. L'exemple de l'histoire Billings présente également une occasion en or pour le synthésiste d'entretenir un lien plus étroit entre la loi et la science sous la forme de dialogue et de collaboration interdisciplinaire ou multidisciplinaire.

\section{NOT A TYPICAL LAWYER...}

Some Ontario lawyers have made a special contribution to Canadian life by engaging in activities or careers outside the practice of law (Sedgwick 1972). Elkanah Billings was one such lawyer, who stands in history as the $19^{\text {th }}$ century father of Canadian paleontology (Fig. 1). He used his exceptional knowledge and researching abilities to peel back the layers of time to reveal the ancient life of the past. Long revered by paleobiologists, paleontologists, geologists, and fossil enthusiasts in Canada and throughout the world for the scope of his pioneering scientific work, Billings has arguably been an 


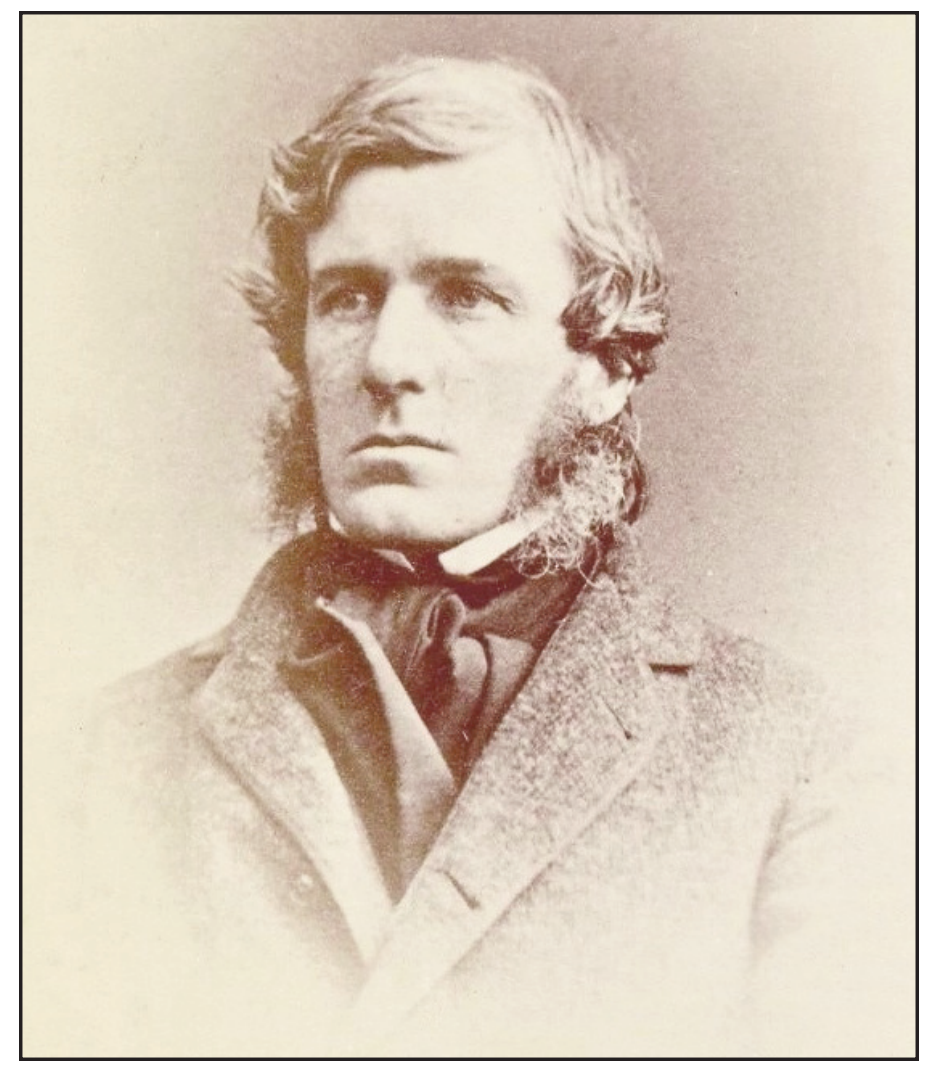

Figure 1. A formal bust portrait of Elkanah Billings by William Notman, dated 1862. From City of Ottawa Archives. Item Number MG002-22-037/CA000423.

unknown in the history of the Ontario legal profession where he began his professional life as a barrister. The Law Society of Upper Canada, the self-governing licensing body and independent regulator of Ontario lawyers since July 17, 1797 and also of Ontario paralegals since May 1, 2007 recognized Billings' work as a paleontologist, perhaps for the first time in the Society's history, in a 2008 online article following an enquiry made by the present author (Lewthwaite 2008). The Ontario legal profession traditionally has paid close attention to recording its collective history, especially significant contributions made by its members to the legal, political, social, and cultural evolution of Ontario and Canada. Although summaries of Billings' life and work have been published since his death, none have been written by a member of the Ontario legal profession. Thus an examination of Billings' professional conduct and career within the context of his duties and responsibilities as a lawyer is arguably overdue. The examination may prove to be informative for lawyers, paleontologists, and interested members of professions and vocations whose careers fall outside the scope of the practice of law or scientific study.

\section{EARLY YEARS}

The beginnings of Billings' history predate the existence of the province of Ontario and the country of Canada. Billings was born on May 5, 1820 in the township of Gloucester on the east bank of the Rideau River in the British North American province of Upper Canada (Whiteaves 1878). Billings' parents came to the province from the United States in 1792 following the American Revolutionary War (Edmond and Uren 2010). Britain's enactment of the Constitutional Act, 1791 created the province to accommodate some of the many thousands of refugees who had fled persecution in the United States because of their loyalty to Britain (United Kingdom 1791). It has been argued that the evidence suggests that the Billings family may have decided to move to Upper Canada primarily for economic reasons (Edmond and Uren 2010). The Billings family holds the distinction of being one of Ottawa's founding pioneer families (Brunton 2004). Their home, constructed during the early decades of the 1800 s, still exists as an Ottawa heritage tourist attraction (Billings Estate National Historic Site 2015).

Billings was initially educated in Gloucester and in Bytown (later Ottawa). He briefly interrupted his education during his early teenage years to try farming, and it has been argued that his apparent unhappiness as a farmer may have been one reason why he decided to run away from home when he was around 16 years old. A relative of Billings recounted that Billings had been hired to cut some wood during the time that he had run away from home. The task involved felling a tree, and Billings injured himself while performing the work. Frustrated, he eventually found himself being persuaded to return home. It was at that time that Billings' parents realized that he "was not cut out to be a farmer" (Edmond and Uren 2010). He subsequently resumed his education by attending the St. Lawrence Academy in Potsdam, New York (Edmond and Uren 2010).

The researchers Martha Edmond and Janet Uren coauthored a significant 2010 Primary Exbibit Research Project, Billings Estate National Historic Site, Final Report on the Billings family for the Billings Estate National Historic Site. Edmond and Uren (2010) argued that the circumstances of various incidents, events, and correspondence concerning Elkanah Billings suggest the possibility that he and his older brother, the botanist Braddish Billings II (Fig. 2), had abused alcohol during their lives. It could be argued that at least some of the allegations concerning alcohol abuse may have been based on circumstantial evidence or speculation. There do not appear to be any records indicating that the issue had ever been brought to the attention of the Law Society of Upper Canada (see Brunton 2004 for information on Braddish Billings II). Although a review of the pervasive consumption of alcohol in $19^{\text {th }}$ century Upper Canada is beyond the scope of this article, studies on the subject have been published by various authors, including the Honourable Morris J. Fish, a retired justice of the Supreme Court of Canada (Fish 2011). Other relevant sources include Bonnycastle (1846), MacFarlane Lizars (1913), Pearson (1914), Wamsley and Kossuth (2000), and Hopper (2015).

Edmond and Uren (2010) also alleged that in 1847 Billings suffered a betrayal by his older brother, who reportedly blackmailed him for attempting to bring 42 law books into Canada from the United States without paying customs duties. It was argued that while Billings admitted his transgression and paid the amount owing for customs duties, it was unclear as to whether the money went to customs authorities or to his older brother for blackmail (Library and Archives Canada 1847 in 


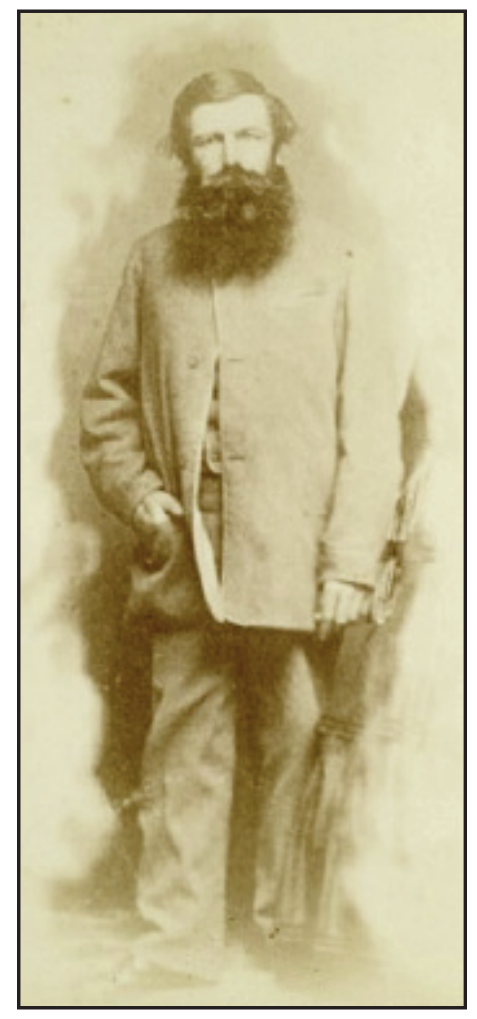

Figure 2. A formal full length portrait of Braddish Billings II by C.W. Parker, ca. 1860, of New York Studio, 140 Sparks Street, Ottawa. From City of Ottawa Archives. Item Number MG002-22-143.

Edmond and Uren 2010). The incident is neither reported nor corroborated in the majority of published accounts of Billings' life.

\section{THE PRACTICE OF LAW}

Billings' career path in the legal profession began in 1839 when he entered into legal training as a student member of the Law Society of Upper Canada. The Society, established by a statute enacted by the Upper Canadian legislature, formed the first statutorily empowered, self-governing bar in the British Empire (Province of Upper Canada 1797). Billings articled with several lawyers in Bytown and in Toronto, including the firm of Adam Wilson and Robert Baldwin, the legendary innovator of Canadian responsible government who forever changed the course of Canadian history (Hamilton 1904; see Cross 2012 for information on Robert Baldwin). Billings was called to the bar in 1844 (Whiteaves 1878). While practising law in Bytown, he formed a brief partnership with the county court judge Christopher Armstrong, but the partnership ended when a law was passed that forbade judges from pleading cases at the bar (Whiteaves 1878). Billings married Helen Walker Wilson, the sister of Adam Wilson, in 1845. They had no children. Edmond and Uren (2010) reported that Helen suffered from weak health, including a possible mental illness. In a November 30, 1865 letter addressed to his mother, Billings stated that "Helen has got quite over her sickness of last spring and summer but she is not strong. The mental derangement of which I wrote you has disappeared altogether" (City of Ottawa Archives 1865 in Edmond and Uren 2010).

Billings practised law in Bytown until 1849, sometimes alone, and sometimes in partnership with another lawyer, Robert Hervey (Whiteaves 1878), who acted as a mentor to Billings' younger brother Charles, while Charles was a law student articling in Bytown from 1848-1852 (Edmond and Uren 2010). Bytown would become the city of Ottawa in 1855, but before that time, the town was a simple outpost that has been described as "a rude little lumber town characterized more by sawdust, beer and brawls than by intellectual achievement" (Brunton 2004).

Billings decided to practise law in Renfrew in 1849. In an August 25, 1849 letter written to his mother, Billings made what Edmond and Uren alleged to be a veiled reference to a struggle with alcohol. Billings stated "I have seen enough now to convince me that I shall succeed here and do better than at Bytown provided I keep in my present state of good health" (City of Ottawa Archives 1849 in Edmond and Uren 2010). Billings soon complained that he felt ostracized in Renfrew because lawyers from Perth had apparently claimed the town as their "territory" for the practice of law (Edmond and Uren 2010). Perth lawyers may have felt justified in establishing their territorial claim because of the location of the courts relative to the surrounding towns. It has been reported that "That part of the country had not yet been set off as a District and all the Courts were held at Perth." Perth lawyers even extended their reach to Bytown, as some of them "had branch offices in Bytown and occasionally sent their older clerks to attend to them" (Riddell 1915). Billings expressed his frustrations to his mother in 1852, commenting that he was "as well qualified to enter as any lawyer in Bytown" (City of Ottawa Archives 2015). He returned to Bytown in 1852 to open a new law office, but it was at this time that he began to change the direction of his career by becoming a journalist (Whiteaves 1878). Notably, Billings began an activity in Renfrew that would have a profound effect on his future: he began collecting fossils (Edmond and Uren 2010).

\section{JOURNALIST AND NATURAL HISTORIAN}

Billings became the editor of the Bytown Citizen (later renamed the Ottawa Citizen) newspaper from 1852-1856 (Brunton 2004). He was known to have engaged in a spirited rivalry with the editor of another local newspaper, the Bytown Gazette (Whiteaves 1878). He was also a member of the Gloucester Township Agricultural Society. Billings helped establish the Bytown Mechanics' Institute on January 20, 1847 as a continuing education facility and library for working men in the absence of a public library or any other "publicly accessible research organizations in Bytown." Billings acted as curator (Klotz 1898; Brunton 2004; Edmond and Uren 2010). The Institute was subsequently reorganized as the Bytown Mechanics' Institute and Athenaeum on January 29, 1853 following a meeting chaired by Judge Armstrong where Billings acted as secretary (Klotz 1898).

Billings developed a great interest in natural science, but there were hardly any venues in Bytown where Billings could research his interest or share it with others. An informal, local group known as the Silurian Society convened meetings to discuss topics in geology, but the evidence is inconclusive as to the extent to which Billings may have participated in their activities (Brunton 2004). Billings wrote articles on natural science topics as editor of the Bytown Citizen and he also reprinted articles from American and European publications (Brunton 2004). It has been argued that the newspaper articles that Billings wrote showed "the enthusiasm of a student just entering upon a new world of inquiry, who has first begun to catch glimpses of his true vocation. They are marked, also, by the absence of that extreme caution which characterized some of his later efforts" (Whiteaves 1878). Billings became a member of the Canadian Institute (Royal Canadian Institute) in 1854, 
publishing his first group of paleontological papers in the Institute's journal. Some of the province's most distinguished citizens, including several lawyers, were members of the Institute. Lawyer members included representatives from the respected Baldwin, Robinson, and Ridout families in Toronto. The council president for 1853-1855 was Chief Justice Sir John Beverley Robinson, one of the most eminent and politically conservative figures in the province. Billings' peers reported that "The papers communicated by Mr. Elkanah Billings, 'On Some New Genera and Species of Cystidea From the Trenton Limestone' would do credit to the transactions of the most distinguished Societies in Europe and America" (Billings 1854; Anonymous 1855). Billings became a member of the Natural History Society of Montreal in 1854. The organization, which existed from 1827-1928, was to become very important in his life (Whiteaves 1878). He also won a cash prize for writing an essay on Canada for the universal exposition in Paris in 1855 (Whiteaves 1878).

Billings' work on the Bytown Citizen, and the concomitant success that he had experienced in publishing articles on natural science, prompted him in 1856 to begin publishing his own journal, which became the first natural science journal in the history of Ontario. The journal, known as the Canadian Naturalist and Quarterly Journal of Science and the Canadian Naturalist and Geologist, covered a range of "delightful and insightful" geological, paleontological, and zoological topics that "demonstrated both excellent powers of observation and a keen appreciation of the importance of documenting the appearance and constitution of original landscape conditions" (Wallace 1948; Brunton 2004). By publishing articles in the journal, Billings could qualify himself as a field geologist (Miller 2007). He also wanted to educate Canadians on the natural history of their land (Whiteaves 1878; Miller 2007). The first year sales of the journal were not sufficient to defray its publishing costs, but Billings' commitment to the cause of education enabled the journal to prevail (Whiteaves 1878). His parents also contributed some financial assistance (Edmond and Uren 2010). In an effort to promote the journal, he provided copies of the first issue to members of the Canadian legislature and to Sir William Logan, the preeminent Canadian geologist with whom Billings had been corresponding since 1852 (Whiteaves 1878; Clark 2004).

\section{VICTORIAN AUTODIDACTS, LEARNED PROFESSIONS, AND MULTIPLE CAREERS}

Because of his intense fascination with natural science and his profound learning skills, Billings became an autodidact (i.e. a self-taught expert) in aspects of biology, zoology, entomology, paleontology, geology, optics, and trigonometry (Whiteaves 1878). By pursuing an interest in natural science, Billings followed the pattern of some Victorian naturalists who had also been trained in the gentlemanly professions of either the law, or medicine, or both. Multiple professions could consequently complement one another, and the juxtaposition of lawyer and natural scientist was not necessarily contradictory or otherwise incompatible (compare with Berger 1983). Dr. William Warren Baldwin, one of the greatest fathers of the Upper Canadian legal profession in the early $19^{\text {th }}$ century, was a lawyer, physician, architect, politician, and judge. His outstanding architectural knowledge was entirely self-taught (Baldwin and Baldwin 1969). Dr. John Rolph, another legendary figure in Upper Canadian history, was a lawyer, physician, and politician. In early $20^{\text {th }}$ century Ontario history, the Honourable Mr. Justice Francis Robert Latchford, chief justice in appeal from 19311938 of what was then known as the Supreme Court of Ontario, was renowned as a published conchologist (Minicucci 2015). Latchford was no stranger to paleontology, having accompanied the legendary Canadian geologist Joseph Burr Tyrrell on field trips for the Geological Survey of Canada in 1881-1882 (Loudon 1930).

Billings' membership in the Law Society of Upper Canada was not terminated as he began turning to journalism and natural science as career choices. He continued to identify himself as "E. Billings, Barrister at Law" as the covers of issues of the Canadian Naturalist and Geologist indicated during the period that Billings was solely responsible for editing and publishing the journal (Brunton 2004). Although Billings never abandoned being a lawyer, he readily acknowledged by 1856 that he had "abandoned" the practice of law for natural science, which "ultimately became the ruling passion of his life" (Whiteaves 1878). Billings understood and accepted that publishing a journal was a difficult enterprise. In a February 29, 1856 letter to Sir William Logan, he admitted "I am well aware that I shall have great difficulties to encounter, but I can overcome them as I have done others" (City of Ottawa Archives 1856 in Whiteaves 1878). The Reverend John Lowry Gourlay, who wrote a comprehensive history of the Ottawa Valley in 1896, fondly recollected Billings as a lawyer and as the publisher of a geological journal:

"Mr. Elkana[h] Billings, the lanyer, we remember in our school days, as a gentleman of talent, energy, and fond of the young science of geology, then coming into notoriety. He left Bytown, and went to Montreal, where he published a geological monthly magazine very bighly spoken of among scholars" (Gourlay 1896).

\section{CREDENTIALISM AND CREDENTIAL MONGERING}

Billings' accomplishments as a paleontologist potentially speak strongly to the issues of credentialism and credential mongering, although the contexts within which one may consider such issues arguably were quite different in the $19^{\text {th }}$ century as compared with the $21^{\text {st }}$ century. The issue of credentialism exists when an excessive reliance is placed upon degrees, diplomas, certificates or professional designations as proof of the attainment of knowledge and competence in a subject. The value of certain credentials may deflate to the point of worthlessness when a sufficient number of people perceive a consequent need to earn the credentials. The issue of credential mongering exists when people attempt to inflate their own importance by using their existing credentials to mislead others into believing that they hold expertise in areas where they have no actual, relevant training.

Billings attained the degree of barrister-at-law as a consequence of being called to the bar. This credential is not a university or law school degree in present-day Ontario, but a license to practise law. The license remains designated as a 
degree because the province of Ontario conferred law degree granting powers on the Law Society of Upper Canada (Province of Ontario 1990). The Society historically maintained a monopoly on the education and licensing of Ontario lawyers until 1957, at which time the responsibility for academically educating Ontario lawyers was delegated to university law schools. The Society, as the regulator of the Ontario legal profession, remains responsible for licensing examinations and an apprenticeship or practical training component. The Society's ability to grant law degrees was a vestige from a time when the Society operated a law school, which subsequently moved to the campus of York University in suburban Toronto in 1968 and became a part of the university (Kyer and Bickenbach 1987). Present-day lawyers in Canada typically possess the tripartite combination of an undergraduate degree conferred by a university, a law degree conferred by an accredited university law school, and a license to practise law granted by the regulator in a Canadian province or territory. Billings and his contemporaries had experienced a significantly different process of lawyer education and licensing.

On deciding to become a professional paleontologist, Billings did not perceive a need to attain university degrees or other related credentials as a means to convince others of the legitimacy of the scientific knowledge and skills that he acquired through self-study and competent practical experience. His prospects of professional advancement as a paleontologist were not predicated on his obtaining a terminal or doctoral degree from a university. A terminal degree was not a necessary corollary to his achieving full professional recognition as a paleontologist. It could be argued that Billings' membership in the legal profession may have afforded him a professional advantage that obviated any need for him to attain additional credentials. Concerning the issue of credential mongering, Billings did not misuse the respected title of barristerat-law to convince others of his authoritativeness as a paleontologist. He arguably may have benefitted from the public respect associated with identifying himself as a lawyer, but relevant and substantive knowledge underpinned his paleontological research. See Loxton and Prothero (2013) for an example of discussions on the issues of credentialism and credential mongering.

\section{CHARACTER, COMPETENCE, AND ACTIVISM}

It is frustratingly difficult to ascertain or evaluate Billings' character and competence as a lawyer based solely on the quality of his work product in the practice of law because nothing of any substantially informative value appears to exist. His work as a paleontologist demonstrates the observational skills, researching skills, and argumentative skills characteristic of a welltrained practitioner of the law. His social views on the law are potentially revealing. It has been argued that Billings' "keen sense of justice was often wounded by what seemed to him unjust juridical decisions, and it is said that he once barely escaped being indicted before the Grand Jury by his former partner Judge Armstrong for remarks published in the Citizen reflecting on one of his judgments" (Whiteaves, 1878). If he was truly an activist lawyer, Billings arguably may have been comparable to some of the more liberal members of the early $19^{\text {th }}$ century legal profession in Upper Canada who sought political, governmental, and social reform. The profession at that time tended to be a bastion of British conservative traditions imported into the province. Billings' overall character has been described as "marked by great firmness and decision, by an unwavering love of truth and justice, and by an unaffected and winning modesty of demeanour" (Whiteaves 1878).

Although it would be acceptable for a lawyer to publicly present legal and public policy arguments to critique a judgment of a court, a personal attack against a judge would be irresponsible according to both $19^{\text {th }}$ century and $21^{\text {st }}$ century standards of professional conduct for Ontario lawyers. Whether acting as plaintiff's counsel, defendant's counsel, Crown prosecutor, or criminal defence, a lawyer must always treat any tribunal, including a court, with utmost respect. The duty applies in court and in public (Law Society of Upper Canada 2014). In the $19^{\text {th }}$ century, the Law Society of Upper Canada and the provincial Court of Queen's Bench could have each taken action against Billings if it had been determined that he had behaved inappropriately towards Judge Armstrong. The court could have struck Billings off its rolls as a solicitor or attorney and the Society could have disbarred Billings by striking him off its rolls as a barrister. See Riddell (1928) for $19^{\text {th }}$ century examples of lawyers being struck off the rolls of the Court of Queen's Bench as solicitors or attorneys and subsequently being struck off the rolls of the Law Society of Upper Canada as barristers. The provincial legislature empowered the Society to assume full jurisdiction over solicitors in addition to barristers in 1857 (Riddell 1916, 1928). Thenceforth, all solicitors became subject to certification and licensing by the Society before being admitted by the courts. All lawyers in the province are consequently barristers and solicitors to the present day.

\section{CANADA'S FIRST PROFESSIONAL PALEONTOLOGIST}

A series of political changes in British North America ultimately precipitated an unexpected opportunity that would change Billings' life forever and enable him to consolidate his reputation as "Canada's first professional paleontologist" (Brunton 2004). A British statute, the Act of Union, 1841, joined together the provinces of Upper Canada and Lower Canada to form the United Province of Canada in 1841 (United Kingdom 1841). The amalgamated province would ultimately be reconstituted as the provinces of Ontario and Quebec when the British North American provinces began uniting as one dominion on July 1, 1867 to form the country of Canada as defined by the Constitution Act, 1867 (United Kingdom 1867). The legislature of the United Province of Canada resolved to perform a geological survey in an effort to assess the province's natural resources, and the Geological Survey of Canada was accordingly inaugurated in 1842, with Sir William Logan being appointed as director of the survey (Harrington 1883).

\section{William Lyon Mackenzie and Charles Fothergill}

During the 1830s, people who had not typically been known for having had any connection to earth sciences, like the radical 
journalist, politician, and Upper Canadian Rebellion of 1837 leader William Lyon Mackenzie, had recognized the need for a geological survey, but nothing had come to fruition during those difficult years (Harrington 1883; Zeller 2009). Against the backdrop of the monumental struggle for responsible government, the province of Upper Canada had endured a tumultuous general election and the beginnings of an economic depression in 1836; a rebellion in 1837; and the Patriot War of 1838-1842. See Guillet (1963) for an overview of these momentous events in the early history of the province of Ontario.

The short-lived York Literary and Philosophical Society, which had formed in 1831, had petitioned the Upper Canadian government in December, 1832 for funds "to provide for an investigation of the geology, mineralogy, and natural history of the Province" but nothing had resulted. Charles Fothergill, the first competent researcher in the natural sciences to have lived in Upper Canada, was one of the individuals who had formed the scientific organization. He had been a journalist, editor, and a member of the Upper Canadian Legislative Assembly from 1824-1830. He had been hobbled by the consequences of his political disagreements with the oligarchical Upper Canadian government during the years that he had served in the virtually powerless Legislative Assembly. He died penniless in 1840 (Harrington 1883; Bailey 1944).

In a surprising and admittedly foolish move, Mackenzie turned against the government agency that he had sought to establish. He publicly castigated Logan and the Geological Survey of Canada in 1858 because Logan had relied upon his profound geological knowledge to deduce that a supposed coal deposit on a farm near Bowmanville, Ontario was a fraud without making a personal visit to the site. Rather than encourage the public to trust Logan's judgment, Mackenzie painted a rather unflattering portrait of the Geological Survey of Cana$\mathrm{da}$ as a group of lofty scholars wasting public funds. Logan's deductions were proven correct: not only did coal not naturally occur in the region at issue, but the perpetrators of the fraud had left evidence of their activities by inadvertently mixing some bread and cheese with the coal that they had placed at the site. When one of Logan's friends eventually brought him a sample of the coal, Logan immediately recognized it as "A good bit of Newcastle coal" (Harrington 1883; Mackenzie 1858 in Gates 1988). So much for criticisms that the Survey did not sufficiently apply itself to practical purposes. The friend with whom Logan had discussed the matter was William Bostford Jarvis (1799-1864), sheriff of the Upper Canadian Home District from 1827-1856; member of the politically conservative Toronto establishment during the early $19^{\text {th }}$ century; and founder of Toronto's Yorkville neighbourhood. Toronto's Rosedale neighbourhood was named after Jarvis' house.

\section{A Career for Life}

When Logan was presented with the opportunity and the government funding to hire a paleontologist to work at the Geological Survey of Canada, he searched for candidates to fill the position. He knew of Billings' published articles on paleontol- ogy, recognized his talents, and secured Billings in 1856 as the Survey's first paleontologist (Whiteaves 1878; Edmond and Uren 2010). Billings relocated to the Survey's base of operations in Montreal, and for the rest of his life he worked at the herculean task of arranging, describing, and classifying the substantial number of fossils that the Survey collected (Whiteaves 1878). He also collected fossils himself, but only from local areas in the United Province of Canada (the provinces of Ontario and Quebec as of July 1, 1867), and in the nearby American states of Vermont and New York (Whiteaves 1878; Clark 2004). In addition, he sought to arrange the fossils in the Survey's geological museum for public exhibition (Whiteaves 1878). The Natural History Society of Montreal took over the duties of editing and publishing the Canadian Naturalist and Geologist after Billings accepted his post at the Geological Survey of Canada (Whiteaves 1878). The name of the journal was amended in 1884 to the Canadian Record of Science, with the first number titled the Canadian Record of Natural History and Geology. Publication was reportedly suspended in 1898 and from 1905-1913, but ultimately ceased in 1916 (Wallace 1948).

Billings briefly visited England and France in 1858. He exchanged ideas with luminaries in the field of paleontology and geology, including Thomas Henry Huxley, Sir Andrew Ramsay, Sir Roderick Murchison, and Joachim Barrande. Huxley may be fairly characterized as one of the greatest $19^{\text {th }}$ century British autodidacts in the natural sciences. As a consequence, he was almost certainly in a position to have fully appreciated the depth and scope of Billings' self-taught knowledge and skills. Billings was similarly in a position to have recognized in Huxley the spirit of a fellow advocate, although Huxley's skills as an advocate would arguably not be definitively exhibited to the public at large until his legendary 1860 Oxford debate on evolution against Samuel Wilberforce. Perhaps it would not be unreasonable to postulate that Huxley's skills in oral advocacy would have made him an ornament to the legal profession in almost any part of the British Empire! See Huxley (1903) for a review of the 1860 Oxford debate. Huxley applied for a professorship in natural history at the University of Toronto in 1851, but when the matter was finally decided in 1853, he was rather astonishingly rejected. The professorship went to William Hincks, the brother of Sir Francis Hincks, who, at the time, served as premier of Canada West for the United Province of Canada (Huxley 1903).

It was at the time of his visit to England and France that Billings was made a fellow of the Geological Society of London (Whiteaves 1878). In a letter written to his father on May 28, 1860 Billings expressed hope that the geological museum of the Geological Survey of Canada would become a permanent institution, affording him with a career in paleontology "for life." Delighted with his paleontological work, he informed his father that "the occupation is exactly what I like and if I can live by it to the last I shall always think myself fortunate" (City of Ottawa Archives 1860). Billings and Logan were acknowledged for developing the geological museum into "one of the principal objects of attraction in the city." The museum was recognized as being "remarkable for the extent 
and variety of rock specimens, and the great number and beauty of the fossils; no geological survey on this or any other continent has been carried forward with greater energy or skill" (Harrington 1883).

\section{WORK PRODUCTIVITY}

Billings published numerous papers in Canadian, American, and English journals during his life. In particular, it has been estimated that he published around 93 articles in the Canadian Naturalist and Geologist (Whiteaves 1878). Billings also contributed to Logan's monumental work Geological Survey of Canada: Report of Progress from its Commencement to 1863 (Logan et al. 1863; Ludvigsen 1979). Some of Billings' greatest published works include Figures and Descriptions of Canadian Organic Remains (Billings et al. 1858, 1859), Palaeozoic Fossils (Billings 1865, 1874), and Catalogues of the Silurian Fossils of the Island of Anticosti, with Descriptions of Some New Genera and Species (Billings 1866). Billings' work should be understood in the context of the times in which he lived. He was one of the world's pioneers in the fledgling science of paleontology. The articles that he published during the period from 1855-1857 predate the revolution in natural science that began in 1859, when Charles Darwin published On The Origin of Species (Darwin 1859; Desilets and Pageau 2003). The beginnings of Billings' work had even predated the significant popularization of paleontology afforded by the 1864 novel Journey to the Centre of the Earth (Voyage au centre de la Terre) by the legendary French author Jules Verne (Butcher 1998). It has been argued that Billings and Logan "were among the vanguard of Victorian scientists gathering clues - deemed crucial for Canada's intellectual and economic development - about the Earth's structure, mineral resources and biological history" (Boswell 2009). Billings wanted to understand fossil organisms in a broader paleobiological and paleoecological context instead of limiting his work to only describing and classifying them.

It has been suggested that Billings had a preference for field work over administrative work, which brought him into disagreement with Logan, who commented to Billings in an April 27, 1869 memorandum that "Your constant absence from the office is a worrying annoyance, particularly as I have reason to suspect that it does not arrive from rheumatism" (Boswell 2009). The matter may have evidenced nothing more than an unremarkable workplace disagreement that almost any earth sciences professional undertaking field work might arguably experience. Edmond and Uren (2010) alleged that alcohol abuse was the reason for Billings' absenteeism, and that Billings should have taken Logan's 1869 memorandum as a warning to cease abusing alcohol (Winder 2004; Edmond and Uren 2010). In a May 26, 1869 letter that Billings' mother wrote to his sister, his mother expressed hope that he and his older brother would "overcome" a "bad habit". She stated: -

"I had a very kind letter from Elkanah in which he writes that he has reformed from a bad habit he thinks that he has overcome the apetite [sic] and that I may rest assured that he will not fall again - and Braddish still continuing in the office all right. I write this to you for I know you will rejoice with me..." (City of Ottawa Archives 1869 in Edmond and Uren 2010).
Billings reportedly sought help through periodic membership in a temperance league (Billings Estate National Historic Site 1978 in Edmond and Uren 2010). Edmond and Uren (2010) alleged that Braddish II and his son Walter ultimately died because of alcohol abuse.

Billings' work productivity was voluminous. It has been reported that he identified around 61 new genera and 1,065 new species of fossil organisms (Ami 1901a). Some of these identifications have withstood the test of time, but others have understandably been subject to revision as methods of paleontological investigation changed or improved over the years and new discoveries were made. The thoroughness of Billings' research ultimately facilitated future interpretations of his discoveries. Billings' work also anticipated the problems associated with researchers unjustifiably splitting one species into several different species, or unjustifiably consolidating several different species into one (Desilets and Pageau 2003). In a subsequent attempt to re-describe some of Billings' fossils, Charles E. Resser (1937) argued that "Billings evidently did little preparatory work on his fossils, preferring to describe them by inference of what was hidden by the matrix." It has been argued that Billings' efforts were limited by the tools and methods available at the time that he performed his research, and by his lack of extensive travel experience and his limited, local field experience (Whiteaves 1878). Although it has been purported that Billings was not the quintessential "field man par excellence" (Copeland 1993) he has nonetheless been credited with describing new genera and species "in a concise and exact manner" (Desilets and Pageau 2003).

\section{DISAGREEMENTS WITH OTHER PALEONTOLOGISTS}

True to his training as a lawyer, Billings was knowledgeable in the literature and he could cite the appropriate sources to support his arguments. He knew how to properly contrast and compare new fossil species with existing descriptions of known fossil species. His legal skills also afforded him the ability to vigorously defend his position, if challenged (Desilets and Pageau 2003).

\section{Dispute with Addison Emery Verrill and William Harmon Niles}

In one incident concerning the fossil organism Pasceolus halli (Fig. 3), two renowned American researchers, Addison Emery Verrill and William Harmon Niles, apparently misinterpreted Billings' analysis of $P$. halli and alleged that Billings had believed that a certain family of fossil organisms (sphaeronitid echinoderms) was related to another group (ascidian chordates) to which the family had no

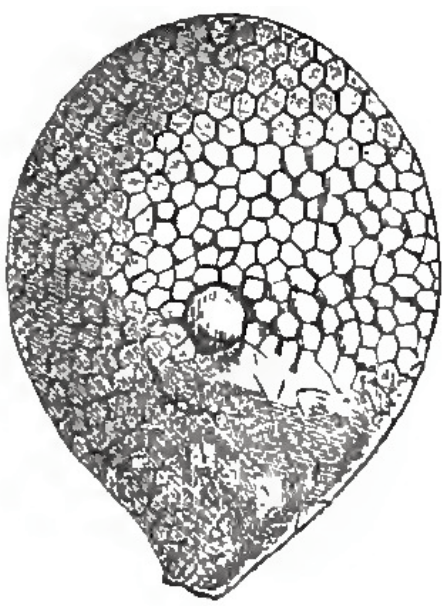

Figure 3. Pasceolus halli. From Billings 1865, figure 366. 
close affinities (Anonymous 1866). The matter was not unusual, controversial or outside the scope of proper scientific investigation, analysis, and debate. But Billings' response is important because it arguably provides further insight into how his legal training had shaped his critical and argumentative skills as a paleontologist. Billings countered Verrill and Niles by reviewing his own work and satisfactorily concluding that "In all that I have written on the subject I cannot find a single remark from which it could be supposed that I ever entertained such an idea." Billings considered P. halli to be a valid, but enigmatic fossil taxon. He demonstrated that Verrill and Niles had based their conclusions in the P. halli matter on unwarranted assumptions and on attempts to connect unrelated facts: the respected researcher, Karl Eduard von Eichwald, had apparently described the genus Pasceolus under the name of the sphaeronitid echinoderm, Cyclocrinites (Billings 1865). Billings subsequently explored the possibility that the affinities of $P$. halli might be with ascidian chordates. Verrill and Niles suggested that it might be a cystidean echinoderm. Verrill and Niles appeared to have drawn the improper conclusion that Billings must have meant to imply that sphaeronitids were closely related to ascidians because von Eichwald's work had connected Pasceolus with sphaeronitid echinoderms and Billings had subsequently connected $P$. halli with ascidian chordates (Billings 1866). Billings applied his skills to unravel what may have appeared to have been a veritable Gordian knot of tangled or misinterpreted facts. Although the affinities of $P$. halli were not definitively resolved, $20^{\text {th }}$ century research found that although chordates and echinoderms are not closely related, they are broadly related as members of the Deuterostomia within the Bilateria.

\section{Disputes with James Hall}

Billings wrote articles that have been characterized as "scathing" concerning the "supposed manipulation of specimens and publication dates" by the renowned American paleontologist and geologist James Hall. It has been argued that Hall's allegedly "opportunistic tactics" in response to Billings' articles "were no match for Billings' legal treatment of the dispute," which rendered Billings' position in the matter "unassailable" by modern scientific standards (Clark 2004). Billings had read that Hall had apparently published a paper purporting to rename a fossil that Billings had previously named. Problems associated with the naming of fossil species have not been rare occurrences in the history of paleontological research. Billings requested a colleague to provide him with a copy of Hall's published paper. In response, Billings unexpectedly received from the colleague some pages that turned out to be Hall's proof sheets, instead of a published paper. The sheets evidenced information and dates of descriptions and names of fossils that suggested to Billings that the subject matter of the proof sheets had previously been published. Hall appeared to have twisted the matter into an opportunity to defame Billings, accusing Billings of improperly obtaining and viewing proof sheets containing data that Hall had not yet published. Billings published an explanation, exposing Hall's accusation as unsupported, vindictive, and sensationalized:
"By blending a mere particle of truth with a great deal that is not true, he has magnified 25 pages obtained unintentionally after publication, into whole volumes of proof sheets procured designedly before. This is only a continuation of the unfair treatment I have received from him during the last four years... I would recommend all persons who may have occasion to read Prof. Hall's papers to examine them closely, as it is not unusual for him especially in questions of priority to arrive at decidedly erroneous conclusions" (Billings 1862).

Billings' disciplined analysis contrasted sharply with Hall's apparent strategy of exaggeration, intimidation, and defamation, and potentially revealed a troubling aspect of Hall's alleged approach to publishing research. Why did material that Hall argued was unpublished apparently contain information and dates suggesting that the subject matter of the material had previously been published? The possible implication is that Hall allegedly attempted to backdate or otherwise manipulate the dates of his descriptions of fossils ostensibly to enable him to gain priority over other researchers, including Billings, in first describing and naming the fossils. If Hall's proof sheets comprised evidence of unethical publication practices, it is doubly ironic that the person who had unexpectedly come into possession of the evidence was on one hand a scientist whom Hall had sought to disadvantage, and who understood the technical implications of the evidence, and on the other hand a lawyer who understood the legal implications of such evidence against Hall, and who could formulate the appropriate legal arguments, accordingly.

Billings alleged that Hall had purposely attempted to frustrate Billings' work by publishing descriptions of Canadian fossils that Hall knew or ought to have known Billings was in the process of describing. Hall allegedly attempted to facilitate his goal by borrowing fossils from Billings' collections without disclosing his true reason for doing so and by procuring fossils from a collector whom he knew was collecting for the Geological Survey of Canada. In contrast, Billings argued that he avoided interfering with Hall's work on New York State fossils by collecting fossils from that state only for the limited purpose of comparing them with Canadian specimens, and not for the purpose of describing and naming them. Billings argued that when he described and named fossils, he did so in an open and transparent manner in the public interest. He appealed to legal concepts of natural justice and procedural fairness, arguing that Hall had acted improperly by violating customary laws of scientific publication: -

"With regard to publication, I bold it to be the duty of an author who describes new fossils to make his work accessible to the public. If he fail [sic] to do this, he cannot claim priority over one who has published in the regular way. His work may be adopted as a matter of courtesy, but not to take precedence over fair publication...

...I hold that there are laws which result spontaneously from the very nature of the circumstances to which they relate. These laws exist perpetually, although not instituted by legislative enactment, and although they may be habitually transgressed by any number of unscrupulous persons. The law of publication is one of these. Every true naturalist instinctively feels and knows that such a law 
does exist, and that it is his duty to observe if' (Billings 1872a). Various codes existed to address issues concerning the naming and classification of animal life, but the issues would not be definitively addressed until the International Commission on Zoological Nomenclature, founded on September 18, 1895, eventually published its first edition of the International Code of Zoological Nomenclature (Melville 1995; International Commission on Zoological Nomenclature 1999). Billings demonstrated that he had no desire to forsake his commitment to ethical professional conduct when he proved that he could respond to personal attacks in a reasoned and civil manner. John M. Clarke, the biographer of James Hall, recounted that Hall and Billings had been amicable and respectful towards one another as "brothers-in-arms" prior to around 1860. Clarke agreed that Billings' work "has not been surpassed in refinement in the field of palaeozoic palaeontology. He was gentle, generous, just, and loyal" (Clark 2004).

\section{SCOPE OF RESEARCH}

Billings sought to correlate strata of the same age in different parts of the world to enable him to gain a better understanding of fossil organisms in a global context (Desilets and Pageau 2003). It has been argued that "his recognition of fossil assemblages was instrumental in the determination of the precise limits and distribution of geologic formations" (Miller 2007). Billings' work enabled Logan to identify the nature of a North American geological feature that Logan termed the Quebec Group, which has since been used to describe a structural feature known as Logan's Line (Clark 2004; Miller 2007). It has been argued that the accomplishment was "first due to a right apprehension of the fossils, for which Mr. Billings deserves much of the credit" (Harrington 1883). Billings' contribution has been described as a "most important and sagacious discovery" (Harrington 1883).

The fossil organisms that Billings researched ranged across geological time. The Paleozoic Era marine organisms that he studied, which lived during various periods from 541-252 million years before the present, included trilobites, brachiopods, molluscs, echinoderms, annelids, bryozoans, cnidarians, poriferans, archaeocyathids, and many other kinds of invertebrate fossils. He also described various Ontario fossil mammals from the Quaternary Period, which is dated from around 2.6 million years ago to the present, including a beluga whale, now classified as Delphinapterus leucas, from Cornwall (Billings 1870; Wagner 1984); a mastodon, now classified as Mammut americanum, from Dunnville (Billings 1869); and a mammoth, now classified as Mammuthus primigenius, from Burlington Heights (Billings 1856, 1863). His paper on the mammoth demonstrated his skills in comparative osteology (Whiteaves 1878). Billings evidently did not limit his research to only one particular group of fossil organisms. His mind and spirit seemed to have been profoundly attuned to the range of past and present life on Earth.

\section{PROOF OF THE EXISTENCE OF PRECAMBRIAN FOSSILS}

The magnitude of one of Billings' accomplishments went almost unrecognized during his lifetime. He described and named the fossil Aspidella terranovica in 1872 based on small, disc-like structures that a geologist had found preserved on rocks from St. John's, Newfoundland (Billings 1872b). Billings made the "bold" decision to identify $A$. terranovica as the preserved evidence of a Precambrian organic structure (Fedonkin et al. 2007). The Precambrian is the part of geological time dated before 541 million years ago. Fossils from this time were virtually unknown in Billings' day, but he was able to correctly interpret the stratigraphic clues to ascertain that $A$. terranovica was from the Precambrian. The apparent absence of preserved Precambrian organisms in the fossil record was a problem that frustrated Darwin in his desire to bolster the theory of evolution by identifying the Precambrian ancestors of fossil organisms already known from the Cambrian Period. Although Darwin was aware of Billings' paleontological publications, he apparently did not realize that Canada's first paleontologist had solved the problem concerning proof of the existence of Precambrian fossils (Ramsay 1859 in Burkhardt and Smith 1985). But many researchers either paid no attention to Billings' classification of $A$. terranovica, or simply doubted that $A$. terranovica represented an organic structure and assumed that Billings' identification was a mistake (Boswell 2009). Some researchers did accept that $A$. terranovica represented "problematical forms... which may be Crustaceans or Mollusks allied to the limpets" from strata "underlying the Lower Cambrian" (Dawson 1897) and perhaps more specifically "apparently referable to the Huronian" (Nicholson 1897). Billings' conclusions on the nature of $A$. terranovica would not be completely vindicated until 2000 , when $A$. terranovica was not only demonstrated to be a fossil consisting of the preserved evidence of a circular holdfast of a sessile, frond-like organism, but was also demonstrated to be the first fossil to have been named from the geological period of the Precambrian known as the Ediacaran Period dated from around 635541 million years before present (Gehling et al. 2000). It has been argued that Billings saw Precambrian fossils "with a clarity that no one did for more than half a century." He recognized that the fossils represented soft-bodied organisms, and that the rocks in which they were found were from a geological age older than the Cambrian Period (Boswell 2009). Billings also wisely declined an opportunity to accept a lead role in supporting the argument made by other researchers that a Precambrian, non-organic geological structure that had been named "Eozoon canadense" was a fossil (Dawson 1897; Clark 2004). Researchers in the $21^{\text {st }}$ century have described many assorted Ediacaran soft-bodied organisms from extraordinary fossil deposits (known as Konservat-Lagerstätten deposits) around the world. Ediacaran fossil deposits from Newfoundland, including the famous Mistaken Point Lagerstätten, are among the richest in the world (Fedonkin et al. 2007; Boswell 2009).

\section{RECOGNITION AND AWARDS}

Billings was recognized for his exceptional work during his lifetime as his scientific reputation spread to various nations. In addition to being made a fellow of the Geological Society of London, he was the vice-president of the Natural History Society of Montreal. It has been reported that he was often 
asked to be president, but he always declined the honour (Whiteaves 1878). He was awarded medals by the International Exhibition of London in 1862; by the Natural History Society of Montreal in 1867; and by the Paris Exposition of 1867 (Whiteaves 1878; Miller 2007). The Paleontology Division of the Geological Association of Canada began awarding the prestigious Elkanah Billings Medal in 1978 (Fig. 4) to "an individual in recognition of an outstanding long-term contribution to any aspect of Canadian paleontology or by a Canadian to paleontology" (Geological Association of Canada 2011). As "a fitting link from past to present" the 1997 recipient of the medal, Thomas E. Bolton, was a curator of the fossil collections that Billings had started (Nowlan and Smith 1998).

\section{THE END OF BILLINGS' LIFE}

Although Edmond and Uren (2010) alleged that Billings struggled with alcohol abuse, he nonetheless evidenced an undisputed dedication to his paleontological work: "Until his health failed him, he was to be found at his desk as early as half-past seven in the morning, and he often took his work home with him at night. He possessed a capacity for brain labour such as falls to the lot of few." He was also reputed to possess "analytical powers of a high order." It has been further suggested that his success as a paleontologist was attributable to his ability to "concentrate his mind on one object." Billings was also known to be an impressive polyglot, being able to read and write in German, Norwegian, Swedish, and Danish (Whiteaves 1878). In addition, several fossil organisms were named in his honour (Ami 1901a). Billings posed for a photograph taken by the renowned Scottish-Canadian photographer William Notman in 1862 (Fig. 1). A painting of Billings by William Raphael was commissioned in 1876 and placed in the hall of the Natural History Society of Montreal. The Ottawa Field-Naturalists' Club commissioned a painting of Billings by Charles E. Moss and presented it to the Geological Survey of Canada in 1900 (Whiteaves 1878; Ami 1901b; Anonymous 1901).

Billings' life ended in Montreal on June 14, 1876 after he suffered for three years from a type of kidney disease historically known as Bright's Disease (Whiteaves 1878). Edmond and Uren (2010) alleged that the illness may have been precipitated by or exacerbated by alcohol abuse (Billings Estate National Historic Site 1978 in Edmond and Uren 2010). As may often be the case when scientists undertake multiple or complex extended projects and perform ongoing research, Billings left "a large amount of unfinished work" at the time of his death (Ami 1901a). The amount of unfinished work may have been inevitable in view of the tremendous amount of fossil material that Billings had been responsible for sorting and classifying during his lifetime. It has been argued that he could have achieved greater accomplishments and he could have continued to revise and refine his work, had he lived longer (Whiteaves 1878). History demonstrated that the long term viability and advancement of paleontological research at the Geological Survey of Canada had not been irrevocably prejudiced by the death of Billings as the incumbent staff paleontologist. The volume, scope, and thoroughness of the work done by Billings and Sir William Logan had laid the appropri-

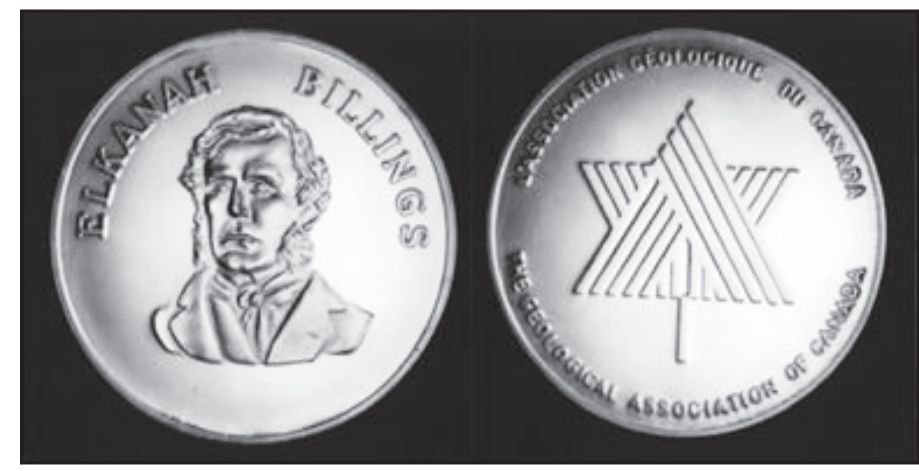

Figure 4. Elkanah Billings Medal awarded by the Geological Association of Canada Paleontology Division since 1978. From Geological Survey of Canada. 1992$054 \mathrm{~A} \& \mathrm{~B}$. Undated.

ate foundations for Billings' successor, Joseph F. Whiteaves. Whiteaves earned a place of distinction in the history of Canadian paleontological research. Of all of the publications on the life and work of Billings, the 1878 obituary authored by Whiteaves arguably remains one of the best.

\section{A Mystery Concerning Billings' Final Resting Place}

Published accounts of Billings' life and work differ on the location of the place of his burial. Records indicate that Billings was buried at Saint Andrew's Presbyterian Church in Montreal (Quebec Vital and Church Records 1876; Bibliothèque et Archives nationales du Québec 1876 in Edmond and Uren 2010; City of Ottawa Archives, undated). It has also been written that he "was buried in the Wilson family plot in Toronto" located at the Toronto Necropolis (Ludvigsen 1979; Clark 2004; Miller 2007) where Billings' wife Helen was subsequently buried when she died on May 4, 1882 (Ontario Registrar General 1882; City of Ottawa Archives, undated). Necropolis records state that Billings died in Montreal on June 14, 1876 from "Dis of Heart" (heart disease?) and that he was buried at the Toronto Necropolis on June 17, 1876 in a plot owned by "G.N. Wilson" (Ontario, Toronto Trust Cemeteries 1876). Assuming that the Necropolis records are correct, if Billings' remains had ever rested at Montreal, a decision must have been made to promptly transfer them to Toronto to inter them at the Necropolis.

\section{LEGACY}

Elkanah Billings is a Canadian historical figure, who has the distinction of being claimed by the global paleontological and geological professional communities, and by the Ontario legal profession (Lewthwaite 2008). It is potentially important for new and emerging Canadian talent in the various branches of the earth sciences and evolutionary biology to be aware of the lives of historical, pioneering researchers, like Billings, in an effort to reinforce the importance of ethics and professional responsibility and to promote a shared sense of professional community and heritage. The example of Billings' history also presents a golden opportunity for the synthesist to nurture a closer connection between the law and science in the form of interdisciplinary or multidisciplinary dialogue and collaboration. The professions and ultimately the public serve to benefit 
as information, issues, systems, and methodologies are shared, discussed, and integrated. With a knowledge of the history of his strengths and weaknesses, and with an understanding of his record of professional accomplishments, members of the Ontario legal profession recognize the status that Elkanah Billings holds in Canadian history by remembering that he was, and always will be, one of their own.

\section{ACKNOWLEDGEMENTS}

I gratefully thank my parents, Elaine and Bruno, and my sister, Andria, for their tremendous support and encouragement in my research. I offer my sincere appreciation to the staff at Geoscience Canada, especially Andrew Kerr, Scientific Editor, Cindy Murphy, Managing Editor, and Robert Raeside, Copyeditor, who each handled the manuscript and to Roger Macqueen, Alexander D. McCracken, and Godfrey Nowlan, who each reviewed it. All offered extremely helpful recommendations and advice on improving the manuscript. Braham Lewandowski of the Billings Estate National Historic Site Museum provided me with a copy of the publication Primary Exbibit Research Project, Billings Estate National Historic Site, Final Report.

\section{REFERENCES}

Ami, H.M., 1901a, Brief biographical sketch of Elkanah Billings: The American Geologist, v. 27, p. 265.

Ami, H.M., 1901b, Annual address of the President of the Ottawa Field-Naturalists' Club: Ottawa Naturalist, v. 14, p. 197-212.

Anonymous, 1855, Canadian Institute. Session 1854-55: Canadian Journal, v. 3, p. 133-141.

Anonymous, 1866, March 2, 1864. Mr. C.K. Dillaway in the Chair: Proceedings of the Boston Society of Natural History, v. 10, p. 19-24.

Anonymous, 1901, Billings Memorial Portrait: The American Geologist, v. 27, p. 198.

Bailey, J.L., Jr., 1944, Charles Fothergill (1782-1840): The Canadian Historical Review, v. 25, p. 376-396, http://dx.doi.org/10.3138/CHR-025-04-02.

Baldwin, R.M., and Baldwin, J., 1969, The Baldwins and the Great Experiment: Longmans, Don Mills, ON, 269 p.

Berger, C., 1983, Science, God and Nature in Victorian Canada: University of Toronto Press, Toronto, ON, $92 \mathrm{p}$.

Bibliothèque et Archives nationales du Québec, 1876, Non-Catholic burials in the Montréal area, 1767-1899. Folio 21 V, Source Centre d'Archives de Montréal, CE 601, S125: www.banq.qc.ca/portal/dt/accueil.jsp; accessed January 1, 2016.

Billings, E., 1854, On some new genera and species of Cystidea from the Trenton Limestone: Canadian Journal, v. 2, p. 215-218, 250-253, 268-274

Billings, E., 1856, On the Mammoth and Mastodon: Canadian Naturalist and Geologist, v. 1, p. 379-390

Billings, E., 1862, Remarks upon Prof. Hall's recent publication entitled: "Contributions to paleontology:" Canadian Naturalist and Geologist and Proceedings of the Natural History Society of Montreal, v. 7, p. 389.

Billings, E., 1863, On the remains of the fossil elephant found in Canada: Canadian Naturalist and Geologist, v. 8, p. 135-147.

Billings, E., 1865, Palaeozoic Fossils, Volume 1, containing descriptions and figures of new or little known species of organic remains from the Silurian rocks 1861-1865: Dawson Brothers, Montreal, PQ, 426 p.

Billings, E., 1866, Catalogues of the Silurian fossils of the Island of Anticosti, with descriptions of some new genera and species: Dawson Brothers, Montreal, PQ, $93 \mathrm{p}$.

Billings, E., 1869, Note on the bones of a mastodon found near Dunnville, October, 1868: Canadian Naturalist and Geologist, v. 6, p. 38-39.

Billings, E., 1870, Bones of a whale lately discovered at Cornwall, Ontario: Canadian Naturalist and Quarterly Journal of Science (New Series), v. 5, p. 438-439.

Billings, E., 1872a, Rejoinder to Prof. Hall's Reply to a "Note on a question of Priority:" American Journal of Science, v. 4, p. 399-400, http://dx.doi.org/ 10.2475/ajs.s3-4.23.399.

Billings, E., 1872b, On some fossils from the Primordial rocks of Newfoundland: Canadian Naturalist and Quarterly Journal of Science, v. 6, p. 465-479

Billings, E., 1874, Palaeozoic Fossils, Volume 2, Part 1: Dawson Brothers, Montreal, 144 p., 9 pl.

Billings, E., Jones, T.R., and Salter, J.W., 1858, Figures and Descriptions of Canadian Organic Remains, Decade III: John Lovell, Montreal, 102 p., 11 pl.

Billings, E., Jones, T.R., and Salter, J.W., 1859, Figures and Descriptions of Canadian Organic Remains, Decade IV: John Lovell, Montreal, 72 p., 10 pl.

Billings Estate National Historic Site, 1978, File 419. Kathy Seaver, Interview with
Amelia, Maria and Hugh Braddish Billings III, 29 January 1978 in Edmond, M., and Uren, J., 2010, Primary Exhibit Research Project, Billings Estate National Historic Site, Final Report, 5 January 2010: Billings Estate National Historic Site, Ottawa, p. 31

Billings Estate National Historic Site, 2015, Billings Estate National Historic Site, Ottawa: http://ottawa.ca/en/liveculture/museums/billingsestate; accessed January 1, 2016.

Bonnycastle, R.H., 1846, Canada and the Canadians, in 1846 in Two Volumes, Vol. 1: Henry Colburn, London, $313 \mathrm{p}$.

Boswell, R., 2009, Lost World: Life in the Primordial World: The Ottawa Citizen Saturday Observer, 19 December 2009.

Brunton, D.F., 2004, Origins and history of the Ottawa Field-Naturalists' Club: The Canadian Field-Naturalist, v. 118, p. 1-38

Burkhardt, F., and Smith, S., editors, 1992, The Correspondence of Charles Darwin, Vol. 7: Cambridge University Press, Cambridge, 671 p.

Butcher, W., editor, 1998, Jules Verne. The Extraordinary Journeys. Journey to the Centre of the Earth. Translated with an Introduction and Notes by William Butcher: Oxford University Press Inc., New York, 234 p.

City of Ottawa Archives, undated, MG2, Billings Family Collection, MG2-20-803, draft by Charles Billings transcribed by Susan Jenkins, undated, p. 24 .

City of Ottawa Archives, 1849, Elkanah Billings to Lamira Billings, 25 August 1849 in Edmond, M., and Uren, J., 2010, Primary Exhibit Research Project, Billings Estate National Historic Site, Final Report, 5 January 2010: Billings Estate National Historic Site, Ottawa, p. 30.

City of Ottawa Archives, 1856, Elkanah Billings to William Logan, 29 February 1856 in Whiteaves, J.F., 1878, Obituary Notice of Elkanah Billings, F.G.S., Paleontologist to the Geological Survey of Canada: Canadian Naturalist and Quarterly Journal of Science (New Series VIII), v. 8, p. 255.

City of Ottawa Archives, 1860, MG2, Billings Family Collection, MG2-1-64, Elkanah Billings to Braddish Billings, Sr., 28 May 1860.

City of Ottawa Archives, 1865, MG1-1-1, Billings Family Collection, Elkanah Billings to Lamira Billings, 30 November 1865 in Edmond, M., and Uren, J., 2010, Primary Exhibit Research Project, Billings Estate National Historic Site, Final Report, 5 January 2010: Billings Estate National Historic Site, Ottawa, p. 31.

City of Ottawa Archives, 1869, Hester Collection, Lamira Billings to Lamira Kilborn, 26 May 1869: Billings Estate National Historic Site, File 369. Photographic copy found at City of Ottawa Archives CA2334, in Edmond, M., and Uren, J., 2010, Primary Exhibit Research Project, Billings Estate National Historic Site, Final Report, 5 January 2010: Billings Estate National Historic Site, Ottawa, p. 117.

City of Ottawa Archives, 2015, Billings Family Virtual Exhibit, Elkanah Billings: http://ottawa.ca/en/rec_culture/museum_heritage/archives/billings_virtual/education/elkanah_billings/index.html; accessed January 1, 2016.

Clark, T.H., 2004, Elkanah Billings (1820-1876) - Canada's first paleontologist, in Macqueen, R.W., ed., 2004, Proud heritage: People and Progress in Early Canadian Geoscience: Geological Association of Canada, Reprint Series \#8, p. 4749.

Copeland, M., 1993, Elkanah Billings (1820-1876) and Joseph F. Whiteaves (18351909): the first two paleontologists of the Geological Survey of Canada: Earth Sciences History, v. 12, p. 107-110, http://dx.doi.org/10.17704/ eshi.12.2.c4311u418x01u11p.

Cross, M.S., 2012, A Biography of Robert Baldwin: The Morning-Star of Memory: Oxford University Press, Toronto, $430 \mathrm{p}$

Darwin, C., 1859, On the Origin of Species by Means of Natural Selection or the Preservation of Favoured Races in the Struggle for Life: John Murray, London, $502 \mathrm{p}$.

Dawson, J.W., 1897, Relics of Primeval Life: Hodder and Stoughton, London, 336 p.

Desilets, A., and Pageau, Y., 2003, Elkanah Billings: Dictionary of Canadian Biography Online, 10, University of Toronto / Université Laval, Toronto and Quebec City: http://www.biographi.ca/009004-119.01-e.php?id_nbr=4835; accessed January 1, 2016.

Edmond, M., and Uren, J., 2010, Primary Exhibit Research Project, Billings Estate National Historic Site, Final Report, 5 January 2010: Billings Estate National Historic Site, Ottawa, 172 p.

Fedonkin, M.A., Gehling, J.G., Grey, K., Narbonne, G.M., and Vickers-Rich, P., 2007, The Rise of Animals: Evolution and Diversification of the Kingdom Animalia: The Johns Hopkins University Press, Baltimore, 344 p.

Fish, The Honourable M.J., 2011, The Effect of Alcohol on the Canadian Constitution... Seriously: McGill Law Journal, v. 57, p. 189-209.

Gates, L.F. 1988, After the Rebellion: The Later Years of William Lyon Mackenzie: Dundurn Press Limited, Toronto, p. 328. 
Gehling, J.G., Narbonne, G.M., and Anderson, M.A., 2000, The first named Ediacaran body fossil, Aspidella terranovica: Palaeontology, v. 43, p. 427-456, http://dx.doi.org/10.1111/j.0031-0239.2000.00134.x.

Geological Association of Canada, 2011, GAC ${ }^{\circledR}$ Divisional Awards, Paleontology Division, Elkanah Billings Medal: http://www.gac.ca/wp/?page_id=2133; accessed January 1, 2016.

Gourlay, J.L., 1896, History of the Ottawa Valley: A Collection of Facts, Events and Reminiscences for Over Half a Century: J.L. Gourlay, Ottawa, 288 p.

Guillet, E.C., 1963, The Lives and Times of The Patriots: The Ontario Publishing Co. Ltd, Toronto, $304 \mathrm{p}$

Hamilton, J.C., 1904, Osgoode Hall: Reminiscences of the Bench and Bar: The Carswell Company, Limited, Toronto, $196 \mathrm{p}$

Harrington, B.J., 1883, Life of Sir William E. Logan, Kt. Montreal: Dawson Brothers, Montreal, $432 \mathrm{p}$.

Hopper, T., 2015, Everyone knows John A. Macdonald was a bit of a drunk, but it's largely forgotten how hard he hit the bottle: National Post, 9 January 2015: http://news.nationalpost.com/2015/01/09/everyone-knows-john-a-macdonald-was-a-bit-of-a-drunk-but-its-largely-forgotten-how-hard-he-hit-the-bottle/ accessed January 1, 2016.

Huxley, L., 1903, Life and Letters of Thomas Henry Huxley, Vol. 1: Macmillan and Co., Limited, Toronto, 463 p.

International Commission on Zoological Nomenclature, 1999, International Code of Zoological Nomenclature, Fourth Edition: The Natural History Museum for the International Trust for Zoological Nomenclature, London, $306 \mathrm{p}$.

Klotz, O.J., 1898, Historical sketch: Transactions of the Ottawa Literary and Scientific Society, v. 1, p. 3-20.

Kyer, C.I., and Bickenbach, J.E., 1987, The Fiercest Debate: Cecil A. Wright, The Benchers, and Legal Education in Ontario 1923-1957: University of Toronto Press for The Osgoode Society, Toronto, $340 \mathrm{p}$

Law Society of Upper Canada, 2014, Law Society of Upper Canada Rules of Professional Conduct, October 1, 2014, R. 5.1-1; 5.1-3; 5.1-5; 5.6-1[3]; 7.1-3[3]; 7.51[1](Law Society Act s.62 (0.1) (10)).

Lewthwaite, S., 2008, Elkanah Billings: Lawyer / Journalist / Paleontologist. The Law Society of Upper Canada Time Capsule: http://www.lsuc.on.ca/ with.aspx?id=424; accessed January 1, 2016.

Library and Archives Canada, 1847, Customs Records, April 1847. RG16, A1 Vol. 265, Ottawa in Edmond, M., and J. Uren, 2010, Primary Exhibit Research Project, Billings Estate National Historic Site, Final Report. 5 January 2010: Billings Estate National Historic Site, Ottawa, p. 118.

Logan, W., Murray, A., Hunt, T.S., and Billings, E., 1863, Geological Survey of Canada: Report of Progress from its Commencement to 1863: Dawson Brothers, Montreal, $983 \mathrm{p}$

Loudon, W.J., 1930, A Canadian Geologist: The Macmillan Company of Canada Limited, Toronto, $257 \mathrm{p}$.

Loxton, D., and Prothero, D.R., 2013, Abominable Science!: Origins of the Yeti, Nessie, and other Famous Cryptids: Columbia University Press, New York, 411 p.

Ludvigsen, R., 1979, Fossils of Ontario Part 1: The Trilobites. Life Sciences Miscellaneous Publications: The Hunter Rose Company for the Royal Ontario Museum, Toronto, $96 \mathrm{p}$.

MacFarlane Lizars, K., 1913, The Valley of the Humber 1615-1913: William Briggs, Toronto, $170 \mathrm{p}$.

Mackenzie, W.L., 1858, Mackenzie's Toronto Weekly Message 4 June 1858 in Gates, L.F., 1988, After the Rebellion: The Later Years of William Lyon Mackenzie: Dundurn Press Limited, Toronto, p. 328.

Melville, R.V., 1995, Towards Stability in the Names of Animals - a History of the International Commission on Zoological Nomenclature 1895-1995: The Natural History Museum for the International Trust for Zoological Nomenclature, London, 104 p.

Miller, W., III, 2007, Trace Fossils: Concepts, Problems, Prospects: Elsevier, Amsterdam, $632 \mathrm{p}$

Minicucci, J.M., 2015, Francis Robert Latchford: Chief justice and naturalist: The Advocates' Journal, v. 33, p. $31-32$.

Nicholson, H.A., 1897, The Ancient Life History of the Earth: D. Appleton and Company, New York, 407 p., http://dx.doi.org/10.1111/j.00310239.2000.00134.x.

Nowlan, G.S., and Smith, C.H., 1998, Memorial to Thomas E. Bolton 1924-1997: Geological Society of America Memorials, v. 29, p. 49-52.

Ontario Registrar General, 1882, Ontario Vital Statistics: Death registration Helen Walker Billings \#021747-82, dated 4 May 1882, registered 16 May 1882 at York County, Division of Toronto, online at Ancestry.com, 6 July 2006.

Ontario, Toronto Trust Cemeteries, 1876, Ontario, Toronto Trust Cemeteries, 1826 1989, index and images, FamilySearch http://www.familysearch.org/pal:/
MM9.1.1/F3G5-Q5Z; accessed 30 Mar 2014. Elkanah Billings, 17 Jun 1876; citing Toronto, Ontario, Canada, section and lot Vault O G 23, line 5520, Volume 05, 1875-1877, Superintendent of Administrative Services; FHL microfilm $1,617,040$.

Pearson, W.H., 1914, Recollections and Records of Toronto of Old with References to Brantford, Kingston, and other Canadian Towns: William Briggs, Toronto, $372 \mathrm{p}$.

Province of Ontario, 1990, Law Society Act, R.S.O. 1990, c. L.8, as amended; s. $60(2)$

Province of Upper Canada, 1797, An Act for better regulating the Practice of the Law, 1797, 37 Geo. III, c. 13, (U.C.).

Quebec Vital and Church Records, 1876, Ancestry.com, online www.Ancestry.com, Quebec Vital and Church Records (Drouin Collection), 1621-1967 [database online]. Provo, Utah, U.S.A.: The Generations Network, Inc., 2008. Original data: Gabriel Drouin, comp. Drouin Collection. Montreal, Quebec, Canada: Institut Généalogique Drouin. Event Year: 1876, Event: Enterrement (Burial), Religion: Presbyterian, Place of Worship or Institution: Montréal (Presbyterian Saint Andrew)

Ramsay, A.C., 1859, Ramsay, A.C. to Darwin, C., 27-30 June 1859, in Burkhardt, F., and Smith, S., eds., 1992, The Correspondence of Charles Darwin, v. 7: Cambridge University Press, Cambridge, p. 313.

Resser, C.E., 1937, Elkanah Billings' Lower Cambrian trilobites and associated species: Journal of Paleontology, v. 11, p. 43-54

Riddell, W.R., 1915, The duel in early Upper Canada: Journal of the American Institute of Criminal Law and Criminology, v. 6, p. 165-176, http://dx.doi.org/ $10.2307 / 1132814$.

Riddell, W.R., 1916, The Legal Profession in Upper Canada in its Early Periods: The Law Society of Upper Canada, Toronto, 194 p.

Riddell, W.R., 1928, The Bar of the Province of Upper Canada or Ontario: The Macmillan Company of Canada Limited, Toronto, 126 p.

Sedgwick, J., 1972, The Contribution to Canadian Life by Members of the Law Society, in Honsberger, J.D., ed., 1972, Law Society of Upper Canada Gazette Commemorative Issue 1797-1972: The Law Society of Upper Canada, Toronto, p. 93-99.

United Kingdom, 1791, Constitutional Act, 1791, 31 Geo. III, c. 31, (U.K.).

United Kingdom, 1841, Act of Union, 1841, 3-4 Vict., c. 35, (U.K.).

United Kingdom, 1867, Constitution Act, 1867, 30-31 Vict., c. 3, (U.K.)

Wagner, F.J.E., 1984, Fossils of Ontario Part 2: Macroinvertebrates and Vertebrates of the Champlain Sea with a Listing of Nonmarine Species. Life Sciences Miscellaneous Publications: The Alger Press for the Royal Ontario Museum, Toronto, $64 \mathrm{p}$.

Wallace, W.S., ed., 1948, The Encyclopedia of Canada, Vol. IV: University Associates of Canada, Limited, Toronto, $400 \mathrm{p}$.

Wamsley, K.B., and Kossuth, R.S., 2000, Fighting It Out in Nineteenth-Century Upper Canada/Canada West: Masculinities and Physical Challenges in the Tavern: Journal of Sport History, v. 27, p. 405-430.

Whiteaves, J.F., 1878, Obituary Notice of Elkanah Billings, F.G.S., Paleontologist to the Geological Survey of Canada: Canadian Naturalist and Quarterly Journal of Science (New Series VIII), v. 8, p. 251-261.

Winder, C.G., 2004, William Edmond Logan (1798-1875) Knighted Canadian Geologist: Trafford Publishing (UK) Ltd., Cheshire, United Kingdom, 203 p.

Zeller, S., 2009, Inventing Canada: Early Victorian Science and the Idea of a Transcontinental Nation: McGill-Queens University Press, Montreal, 372 p.

\section{Received February 2016 \\ Accepted as revised June 2016 \\ First published on the web August 2016}

